\title{
Antioxidants and dairy production: the example of flax
}

\author{
Hélène V. Petit ${ }^{1}$ \\ ${ }^{1}$ Dairy and Swine Research and Development Centre, Agriculture and Agri-Food Canada, P. O. Box 90, Stn Lennoxville, Sherbrooke, QC \\ J1M 1Z3, Canada.
}

\begin{abstract}
This manuscript reports on the main problems decreasing productivity of dairy cows (e.g. fatty liver syndrome and poor fertility) and how antioxidants could enhance it. High producing dairy cows are prone to oxidative stress, and the situation can be exacerbated under certain environmental, physiological, and dietary conditions. Antioxidants have important effects on the expression of genes involved in the antioxidant status, which may enhance animal health and reproduction. Moreover, antioxidants may contribute to decrease the incidence of spontaneous oxidized flavour in milk enriched in polyunsaturated fatty acids. Plant lignans are strong antioxidants and flax is the richest source of plant lignans. Flax lignans are converted in the mammalian lignans enterolactone and enterodiol. The main mammalian lignan in milk is enterolactone and flax lignans are converted in enterolactone mainly under the action of ruminal microbiota. Therefore, ruminal microbiota may be the most important flora to target for plant lignan metabolism in order to increase concentration of mammalian lignan antioxidants in milk of dairy cows. However, more research is required to improve our knowledge on metabolism of other antioxidants in dairy cows and how they can contribute in decreasing milk oxidation.
\end{abstract}

Key Words: antioxidant, bovine, flaxseed, metabolism

\section{Antioxidantes e produção leiteira: o exemplo da linhaça}

RESUMO - O artigo aborda os principais problemas na diminuição da produtividade de vacas leiteiras (por exemplo, síndrome do fígado gorduroso e baixa fertilidade) e como antioxidantes podem melhorá-los. Vacas de alta produção são propensas ao estresse oxidativo, e a situação pode ser exacerbada sob certas condições ambientais, fisiológicas e de alimentação. Os antioxidantes têm importantes efeitos na expressão de genes envolvidos no status antioxidante, o qual pode melhorar a saúde animal e a reprodução. Além disso, os antioxidantes podem contribuir na diminuição da incidência de oxidação espontânea no leite enriquecido com ácidos graxos poli-insaturados. Lignanas vegetais são potentes antioxidantes e a semente de linhaça é a mais rica fonte de lignanas vegetais. As lignanas presentes na semente de linhaça são convertidas em lignanas mamíferas, enterolactona e enterodiol. A principal lignana mamífera no leite é a enterolactona e as lignanas da linhaça são convertidas em enterolactona principalmente sob a ação da flora ruminal. Assim, a flora ruminal pode ser a mais importante flora objetivando o metabolismo de lignanas vegetais para aumentar a concentração de antioxidantes como lignanas mamíferas no leite de vacas. No entanto, mais pesquisas são necessárias para melhorar nosso conhecimento sobre o metabolismo de outros antioxidantes em vacas leiteiras e como eles podem contribuir na diminuição da oxidação do leite.

Palavras-chave: antioxidante, bovinos, metabolismo, semente de linhaça

\section{Introduction}

The transition period, from $3 \mathrm{wk}$ before to $3 \mathrm{wk}$ after parturition, has important effects on health, production, and profitability of dairy cows. During this period, intake of energy does not meet the requirements for milk production, which results in negative energy balance. In early lactation, excessive lipid mobilization from adipose tissue, muscle, and other tissues occurs to support requirements for maintenance and milk production. Body fat mobilization induces an increase in plasma non-esterified fatty acids (NEFA) uptake by the liver, a greater fatty acid (FA) esterification than FA oxidation, triglycerides (TG) accumulation leading to the development of fatty liver, inadequate gluconeogenesis (for review: see Drackley, 1999), and decreased ureagenesis (Strang et al., 1998). The concentration of NEFA is the major determining factor of TG accumulation in the ruminant liver. Circulating NEFA concentrations are absorbed by the liver where some are reesterified to TG before being secreted in blood as very low density lipoproteins (Herdt et al., 1988). However, when the intrahepatic NEFA concentrations increase very rapidly as a result of intensive lipolysis, the liver cannot increase the production of very low density lipoproteins comparable 
with the production of TG synthesis. As a consequence, the liver accumulates a greater amount of TG, resulting in aberrant hepatic function, lower productivity, reduced feed intake, and poor reproductive performance in dairy cows (Herdt, 1988). Generation of free radicals during peroxidation of essential FA in the lipid membranes can damage cells and impair the production and health status of the animal (Miller \& Brezeinska-Slebodizinska, 1993).

Fertility of cows with fatty liver syndrome is generally poor. Dairy cow fertility is actually undergoing a steady decline with first service conception rates below $50 \%$ in most herds and an estimated $1 \%$ decrease in conception rate every year, which is coupled with increased milk yield (Lamming et al., 1998). In Canada, we observe high involuntary culling rates (34\%), a cost due to increased embryo mortality (Plaizier et al., 1997) and poor conception rates (Kinsel \& Etherington, 1998) as well as a negative relationship between production and infertility (Etherington et al., 1996). In order to improve fertility and the energy balance of cows after calving, fat sources are often used to increase the energy density of the diet. However, dietary lipids such as supplemental fat, oil seeds, and distiller grains, if not stabilized, can be significant contributors to the load of free radicals in the animal (Andrews et al., 2006). Decreased performance, increased gut turnover, and compromised immune response have been reported in production animals fed oxidized fat (Cabel et al., 1988; Dibner et al., 1996).

Over the past 10 years it has become evident that FA can regulate cellular functions by modulating gene expression (Grimaldi, 2001). Moreover, it is now well accepted that omega 3 and omega 6 FA play pivotal roles in transcription of genes involved in lipogenesis, glycolysis, glucose transporters, inflammation, early gene expression and vascular cell adhesion molecules (Clarke, 2001). Some antioxidants such as sesamin lignans also increase the expression of genes involved in â-oxidation of rats (Kiso, 2004). As flaxseed is rich in plant lignans antioxidants, they could enhance health of animals. In fact, flaxseed antioxidants enhance endogenous level response by upregulating the expression of genes encoding the enzymes such as superoxide dismutase, catalase, and peroxidase (Rajesha et al., 2006), which are involved in the antioxidant status. Our recent results (Petit et al., unpublished) have shown that flaxseed hulls, a rich source of plant lignan antioxidants (Prasad, 2000), affect the expression of genes involved in oxidative stress in the mammary gland, which may contribute to improve animal health and reproduction.
Oxidative metabolism is essential for survival of cells. A side effect of this dependence is the production of free radicals and other reactive oxygen species that cause oxidative changes. High producing dairy cows are prone to oxidative stress, and the situation can be exacerbated under certain environmental, physiological, and dietary conditions (Bernabucci et al., 2005; Castillo et al., 2005). However, specific feeding strategies may contribute to enhance immunity and the antioxidant status as shown by the decrease in the proliferative response of mononuclear cells transiently at the time of embryo implantation in dairy cows fed whole flaxseed (Lessard et al., 2003). Moreover, inclusion of antioxidants in the diet ameliorates the negative effects of oxidized fat by scavenging peroxides and reducing peroxidation of FA (Frankel, 2005) and enhances lactation performance and tantioxidant status of cows (VázquezAñón et al., 2008). Supplementation with antioxidants before the beginning of months of heat-stress and also during the stress period may correct the infertility due to heat-stress through decreased cortisol secretion and oxidative stress, resulting in enhanced pregnancy rates (Megahed et al., 2008). Moreover, strong positive correlations between several antioxidant enzymes (e.g. glutathione peroxidase) and vascular adhesion molecules suggest a protective response of antioxidants to an enhanced proinflammatory state in transition dairy cows (Aitken et al., 2009). Antioxidants then could contribute to enhance mechanisms against oxidative stress with various immunity, reproduction, and health benefits.

\section{Antioxidants and milk oxidation}

Over the last three decades, milk fat has been criticized because of its higher content in saturated FA than in polyunsaturated FA. Intake of saturated FA has been linked to increased cardiovascular diseases due to increased blood cholesterol (Grundy and Denke, 1990) while polyunsaturated FA, such as omega-3 FA, has been demonstrated to decrease risk factor of coronary heart diseases (Simopoulos, 2002). As a result, nutritionists began to feed dairy cows with supplements high in polyunsaturated FA protected against ruminal biohydrogenation by microbes to modify milk FA composition. For example, soybeans are high in polyunsaturated FA, and feeding roasted soybeans increases the proportion of those FA in milk fat, especially linoleic $\left(\mathrm{C}_{18: 2}\right)$ and linolenic $\left(\mathrm{C}_{18: 3}\right)$ acids (Dhiman et al., 1999). Unfortunately, although feeding roasted soybeans increases polyunsaturated FA in milk fat, it also increases the likelihood of oxidized flavour in milk (Timmons et al., 
2001). Numerous studies have characterized spontaneous oxidized flavour (SOF) and extensive efforts to define the causes of SOF have been undertaken (Charmley \& Nicholson, 1994; Barrefors et al., 1995). In general, milk with higher concentrations of linoleic acid is more susceptible to oxidation (Sidhy et al., 1975).

Oxidized flavour of milk is described as being metallic, cardboardy, tallowdy, or fishy and reduces the acceptability of dairy products by the consumer. Spontaneous oxidized flavour develops without the addition of exogenous oxidants (e.g. $\mathrm{Cu}$ ) or without exposure to light. The SOF is a result of the production of volatile aldehydes and other carbonyl compounds after the formation of hydroperoxides (Frankel, 1991) from the oxidation of pentadienyl groups in polyunsaturated FA. The oxidative process is autocatalytic, requiring only one initiating radical to start the production of lipid hydroperoxides; thus, SOF intensifies as storage time increases. The susceptibility of milk to SOF varies. Some milk develops SOF very rapidly (detectable in the bulk tank), but other milk may not develop SOF until after several days of storage. Most commercial dairy herds have only a small number of cows $(<10 \%)$ producing milk susceptible to SOF, but SOF is detectable in bulk tank milk only when $>30 \%$ of the herd is affected (Nicholson \& Charmley, 1991). Therefore, one way of preventing milk oxidation could be the use of antioxidants.

Natural antioxidant molecules such as vitamin E act as free radical scavengers (Miller et al., 1993). The amount of vitamin $\mathrm{E}$ associated with the fat globule membrane is considered to be the main determinant of the oxidative stability of milk. In earlier trials conducted mainly in Canada (Nicholson \& St-Laurent, 1991; Charmley \& Nicholson, 1994), dietary supplementation of vitamin E did not consistently increase the -tocopherol concentration in milk. However, the oxidative stability of milk, as estimated by a panel of three trained evaluators, generally increased (Nicholson \& St-Laurent, 1991). Dietary vitamin E supplementation at $9954 \mathrm{IU} / \mathrm{d}$ increased the "tocopherol concentration in milk by about $45 \%$, which was sufficient to prevent milk oxidation (Focant et al., 1998). However, the efficiency of transfer of supplementary dietary "-tocopherol to milk is usually low with values of approximately $0.27 \%$ (Charmley et al., 1993) and the role of "-tocopherol on the oxidative stability of the milk appears to be less important than the variation in the FA profile (Havemose et al., 2006). Therefore, more research is required to better understand the relationship between antioxidant supplementation and milk oxidation.

\section{Metabolism of flaxseed lignans}

Flaxseed (Linum usitatissimum) is an excellent source of polyunsaturated oil in the form of á-linolenic acid and is the richest source of plant lignans (Thompson et al., 1991). Lignans are one of the three main classes of polyphenolic compounds with isoflavones and coumestans and they are classified as phytoestrogens (Stopper et al. 2005). Lignans have a wide range of biological activities, including antioxidant, antitumor, weakly estrogenic and antiestrogenic properties. Greater intakes of flaxseed by human have been linked to potentialhealth benefits, especially in the prevention of cardiovascular diseases, hypercholesterolemia, monopausal symptoms, and breast and prostate cancers (Thompson \& Ward, 2002). The study of Saarinen et al. (2008) on the distribution of absorbed lignans in rat models fed ${ }^{3} \mathrm{H}-\mathrm{SDG}$ showed the presence of lignans in liver, kidney, breast tumors, spleen, skin, lung, brain, uterus and adipose tissues. This indicates that lignans may have local effects in tissues such as tumor tissue that may contribute to human breast cancer prevention.

Secoisolariciresinol diglucoside (SDG) represents over $95 \%$ of the total lignans in flaxseed (Liu et al., 2006). Flax lignans are concentrated in the outer fibre-containing layers (Adlercreutz \& Mazur, 1997), thus resulting in higher concentration of SDG in hulls than seeds (Côrtes et al., 2008). In non-ruminant animals, SDG is converted (Figure 1) into secoisolariciresinol (SECO) under the action of intestinal glycosidases (Saarinen et al., 2002) and the colonic microbiota convert SECO to mammalian lignans, enterodiol (ED) and enterolactone (EL; Setchell et al., 1980).

Mammalian lignans are absorbed by the intestine and under the action of specific enzymes they are conjugatedas sulphates and glucuronides in the intestinal wall and liver (Jansen et al., 2005). They are excreted in physiological fluids (e.g. plasma and urine) or returned to the intestinal lumen via enterohepatic circulation (Hoikkala et al., 2003). The conjugated forms of mammalian lignans ae poorly absorbed by the intestine; deconjugation increases the hydrophobicity of lignans and allows their reabsorption. The mammalian lignans are more resistant to cellular enzymes but are readily cleaved by microbial â-glucuronidase. This enzyme plays an important role for optimal absorption of mammalian lignans (Raffaelli et al., 2002). Variation in intestinal microflora also plays an important role in the interindividual variation metabolism of SDG (Raffaelli et al., 2002). Moreover, there is a fivefold increase in urine excretion of EL in rats fed pure EL compared with those fed plant lignans (Saarinen et al., 2002), suggesting that absorption 


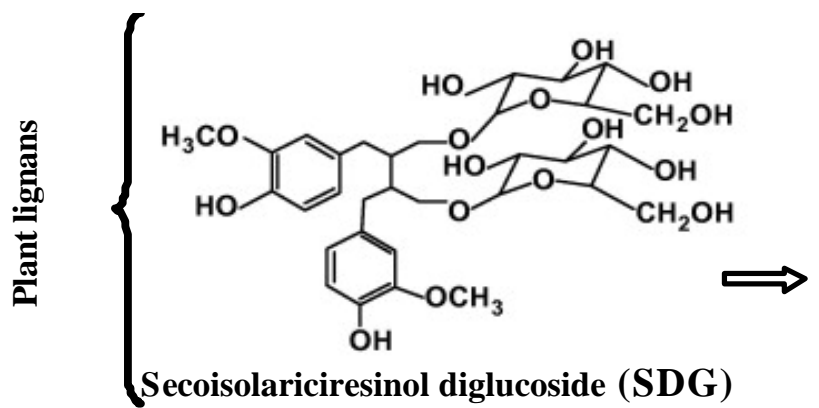<smiles>COc1cc(CC(CO)C(CO)Cc2ccc(O)c(OC)c2)ccc1O</smiles>
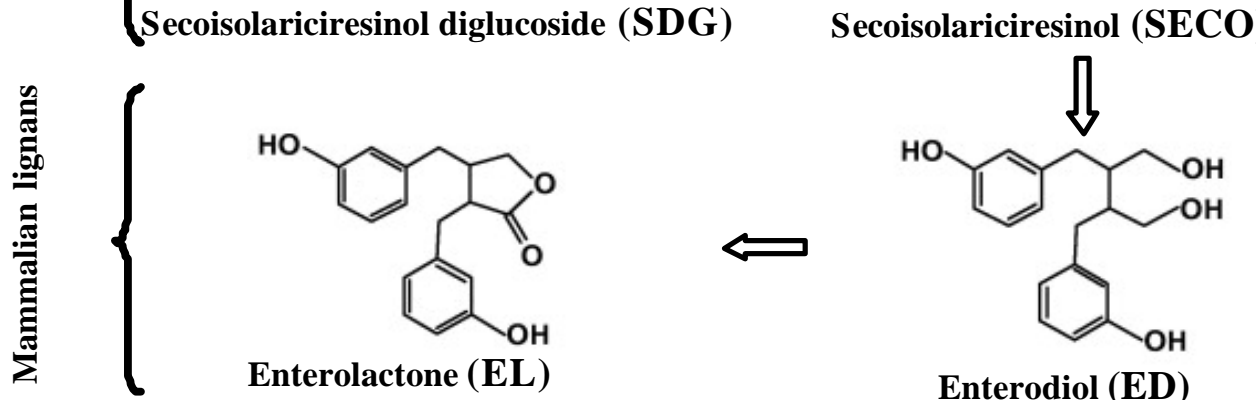

Figure 1 - Chemical structures of the plant lignan secoisolariciresinol diglucoside and its metabolites.

of mammalian lignans is higher than that of plant lignans. Milk with an elevated EL content may then be interesting as a dietary source of EL and an excellent strategy to optimize the effects of lignans on human health. Indeed, milk bioactive molecules may find use in the treatment of various diseases such as oxidative stress and immunodeficiency (Haque et al., 2009).

The flaxseed lignan and its mammalian metabolites have been reported to exert protective effects against dietrelated chronic diseases through a variety of mechanisms including antioxidant effects. This is of particular interest as many chronic diseases are characterized by an oxidative stress component (Pool-Zobel et al., 2000). Prasad (2000) reported that millimolar concentrations of SECO, ED, and EL inhibited reactive oxygen species-initiated chemiluminescence following an in vitro incubation of venous blood. Greater amounts of mammalian lignans reaching the mammary gland also could contribute to increase milk yield as greater in vitro proliferation of mammary epithelial cell of prepubertal heifers has been reported with the mammalian lignan EL addition in the culture media (Purup et al., 2002), thus suggesting a possible role of EL on mammary development and lactation in cattle.

Different studies have confirmed the presence of polyphenolic compounds such as equol, daidzein, and genistein (Bannwart et al., 1988; King et al., 1998) and mammalian lignan EL (Petit et al., 2005) in the milk of dairy cows. Feeding flax meal to dairy cows resulted in a linear increase of EL concentration in milk but ED was not detected (Petit et al., in press). In non-ruminant animals, intestinal fermentation plays important role in the metabolism of plant lignans to mammalian lignans, ED and EL. Recent in vitro results have shown that the main mammalian lignan metabolite produced from flax hulls by ruminal microbiota of dairy cows was EL, while fecal microbiota led mainly to the net production of ED (Côrtes et al., 2008). Otherin vivo results have reported that ruminal microbiota of goats convert SDG to ED and EL, and that EL is the main lignan metabolite present in ruminal fluid and plasma (Zhou et al., 2008). However, feeding polyunsaturated FA is known to modify ruminal microbiota (Maia et al., 2007), which could interfere with the ruminal metabolism of flax lignans, affecting the concentration of its metabolites in biological fluids. Therefore, the common practice of feeding supplemental sources of polyunsaturated FA may interact with the metabolism of antioxidants in the rumen and requires more research.

Metabolism of antioxidants: the example of flax lignans

Phytoestrogens such as isoflavones are metabolized by rumen microbes (Dickinson et al., 1988) and their absorption takes place mainly in the rumen (Lundh et al., 1990). However, the activity of ruminant microbiota for the conversion of flax lignans to mammalian lignans is unknown. Greater concentrations of mammalian lignan metabolites in milk could result in health benefits but more information on 
the metabolism of flax lignans is required to enable targeted modification of the concentration of mammalian lignans in milk. The first step to undertake is to better understand the metabolism of antioxidants in order to increase their transfer in tissues and milk. Therefore, we undertook a research program to determine the in vitro conversion of plant lignans from flax products into the mammalian lignans EL and ED by bovine ruminal and fecal microbiota and to investigate the importance of the site of administration (rumen and abomasum) of flax oil and flax hulls on the conversion of plant lignans into the mammalian lignan EL and the consequent concentration of EL in blood, ruminal fluid, urine, and milk of dairy cows.

\section{Conversion of plant lignans antioxidants from flax}

The objective of the first experiment was to determine the in vitro conversion of plant lignans from two flax products (hull and seed) into the mammalian lignans EL and ED by bovine ruminal and fecal microbiota. At initiation of the incubation $(0 \mathrm{~h})$, the lignan metabolites produced from ground flax hulls were not detected. During incubation, there was net production of SECO from SDG by both ruminal and fecal microbiota as shown by the HPLC chromatographic profiles, which may result from hydrolyzation of SDG in SECO under the action of intestinal glycosidases (Saarinen et al., 2002). Previous results have shown that the activity of intestinal glycosidases is from enzymes of mammalian (Day et al., 1998) and microbial (Saarinen et al., 2002) origin. However, the ruminal epithelium is non-secretory and epithelial cells were absent in our in vitro model, suggesting that the origin of intestinal glycosidases was from microbiota. At the end of the incubation (96 h), EL was the major metabolite detected with ruminal microbiota while the major metabolite detected with fecal microbiota was ED.

Greater net production of ED than EL by ruminal microbiota was observed at $6 \mathrm{~h}$ of incubation, thus suggesting that the first step in mammalian lignan production by ruminal microbiota from SECO was ED, the precursor leading to EL production. This would agree with the results of Borriello et al. (1985) who have reported that SECO incubated with human fecal microbiota led first to the production of ED. Similarly, a delay between production of ED and that of EL has been reported for flax seed incubated with human fecal microbiota in an in vitro fermentation system (Aura et al., 2006). Net production of ED was higher than that of EL by fecal microbiota, suggesting that the main mammalian lignan produced by fecal microbiota from a rich source of plant SDG is ED. On the other hand, results indicate that the main mammalian lignan produced by ruminal microbiota from flax products rich in plant SDG is EL.

In vivo metabolism of plant lignans from flax

Many studies have reported that intestinal microorganisms play an important role in phytoestrogen metabolism (Borriello et al., 1985; Bowey et al., 2003). In ruminants, fermentation processes occur first in the rumen as opposed to non-ruminant animals, where they take place in the colon. Previous studies with ruminant animals have shown that lignan metabolites are present in biological fluids such as plasma, semen, and milk (Dehennin et al., 2002; Hansen-Møller and Kristensen, 2004; Petit et al., 2005). According to ourin vitro results (Côrtes et al., 2008), ruminal microbiota of dairy cows has the ability to metabolize lignans from flax products to mammalian lignan EL. Other dietary feed ingredients such as forages and cereals also contain lignans (Steinshamn et al., 2008), which may lead to EL production and explain the presence of EL in ruminal fluid of cows fed diets with or without flax products (Gagnon et al., In Press). Results from a recent in vitro study (Maia et al., 2007) reported that growth of ruminal bacteria can be affected by polyunsaturated FA such as omega- 3 although sensitivity differs among species, which may affect metabolism of plant lignan antioxidants in the rumen.

After absorption by the intestine, conjugated mammalian lignans return to the intestinal lumen via enterohepatic circulation or are excreted in physiological fluids. Although many studies have shown the presence of lignans in plasma and milk of dairy cows, none has investigated the role of the rumen in the transfer of mammalian lignans in biological fluids such as plasma, urine, and milk. Our recent study (Gagnon et al., In Press) shows that concentration of EL obtained in urine and milk depends on ruminal metabolism of plant lignans although there is no difference in EL concentration in the rumen (Figure 2A) and plasma (Figure 2B). A significant increase in EL concentration was observed in urine (Figure 2C) and milk (Figure 2D) of cows when a source of lignans (flax hulls) was placed directly in the rumen compared to when lignans bypassed the rumen through administration in the abomasum. Therefore, it appears that the main site for metabolism of flax lignans in dairy cows is the rumen and that the small and large intestine are not as efficient to metabolize plant SDG into mammalian EL. The response to plant lignan SDG supplementation was more important in urine and milk than blood. Increases in EL concentration of milk and urine were, respectively, 12 and 16 times higher for cows receiving both flax products (hulls + oil) in the rumen 


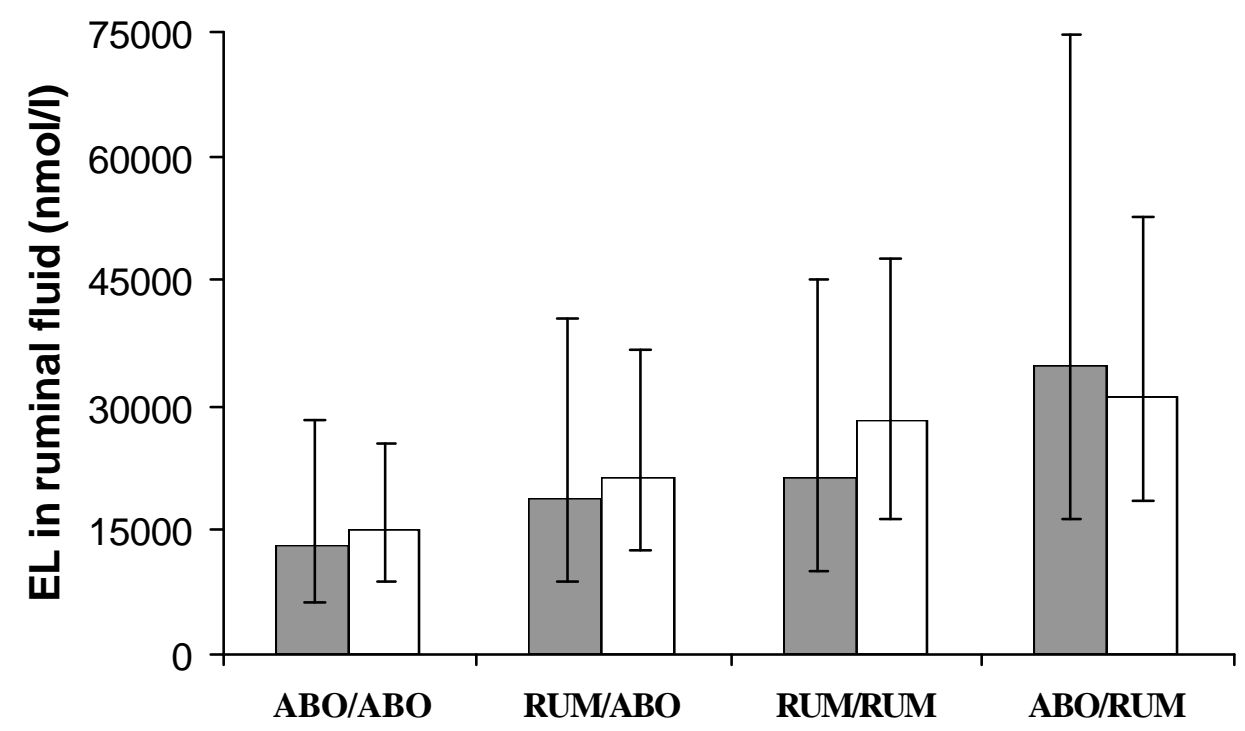

Figure $2 \mathrm{~A}$ - Concentration of enterolactone (EL) in the rumen before $(\%, 0 \mathrm{~h})$ and after feeding $(i \%$, pooled samples for 2,4 , and 6 h) of dairy cows supplemented with flax hulls and flax oil. Treatments were: 1$)$ oil and hulls infused in the abomasum (ABO/ ABO); 2) oil placed in the rumen and hulls infused in the abomasum (RUM/ABO); 3) oil and hulls placed in the rumen (RUM/RUM); and 4) oil infused in the abomasum and hulls placed in the rumen (ABO/RUM). Data are the mean values with confidence intervals represented by vertical bars.

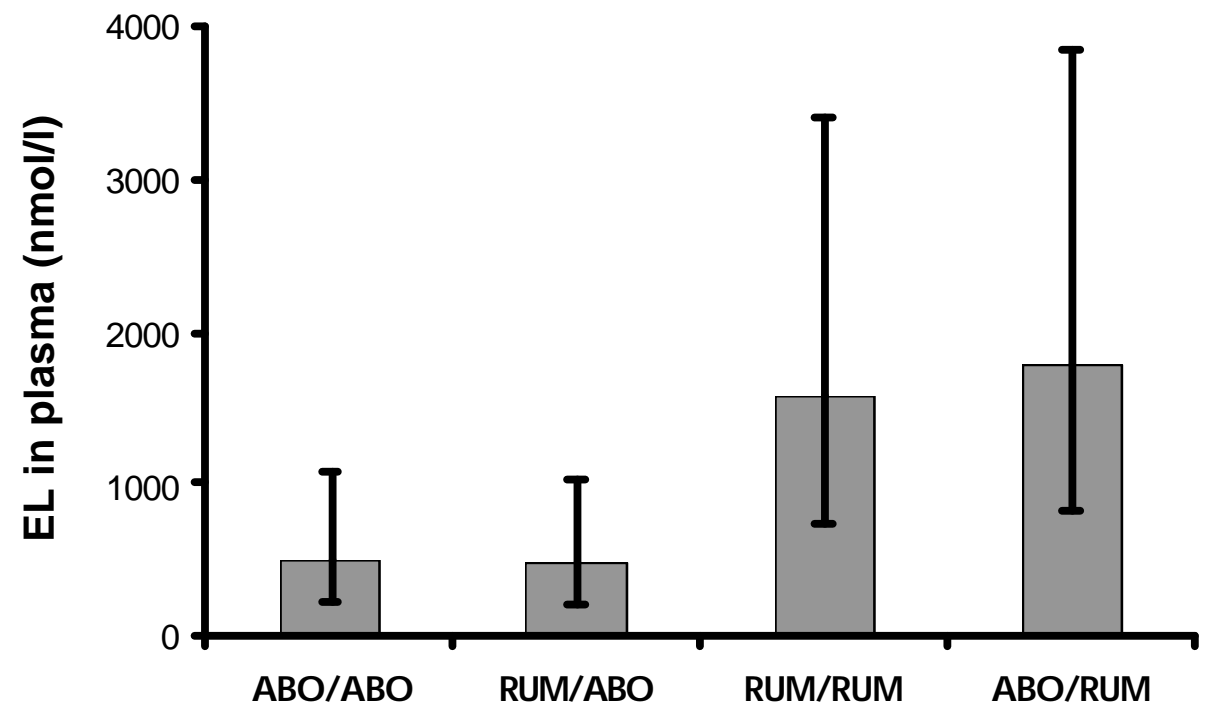

Figure 2B - Concentration of enterolactone (EL) in plasma of dairy cows supplemented with flax hulls and flax oil. Treatments were: 1) oil and hulls infused in the abomasum (ABO/ABO); 2) oil placed in the rumen and hulls infused in the abomasum (RUM/ABO); 3 ) oil and hulls placed in the rumen (RUM/RUM); and 4) oil infused in the abomasum and hulls placed in the rumen (ABO/ RUM). Data are the mean values with confidence intervals represented by vertical bars. Concentration of EL in plasma was different $(\mathrm{P}=0.04)$ among treatments. 


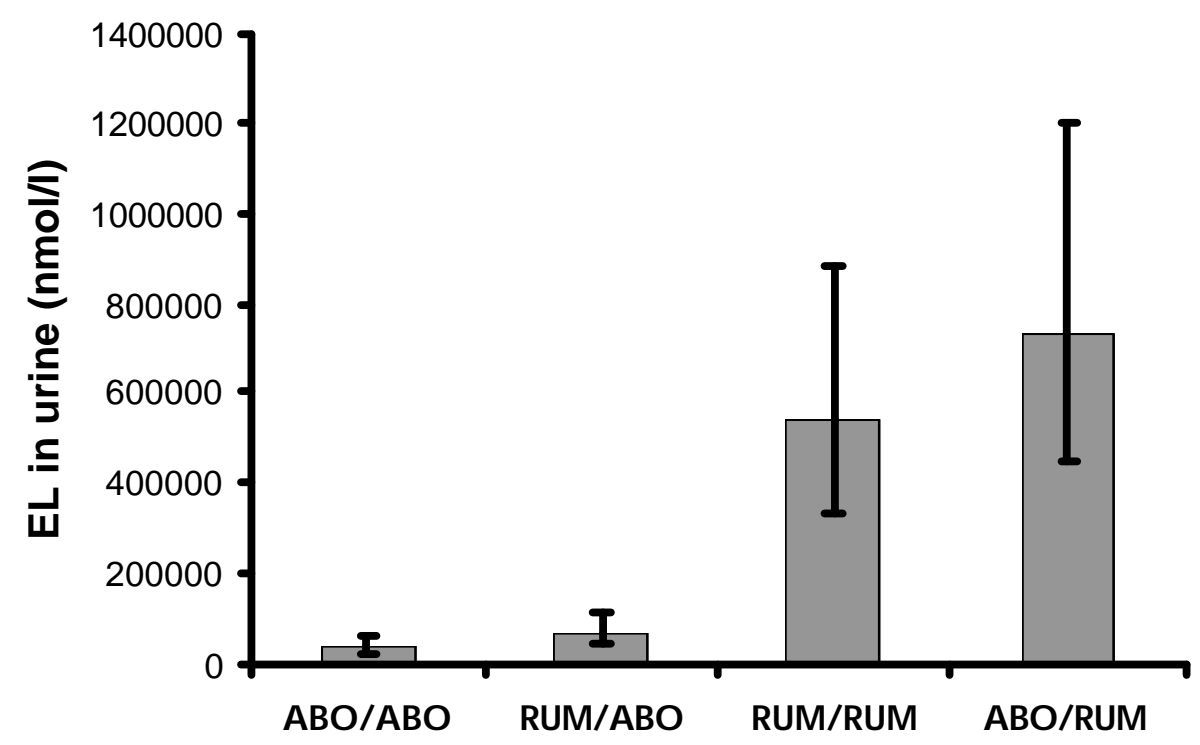

Figure 2C - Concentration of enterolactone (EL) in urine of dairy cows supplemented with flax hulls and flax oil. Treatments were: 1) oil and hulls infused in the abomasum (ABO/ABO); 2) oil placed in the rumen and hulls infused in the abomasum (RUM/ABO); 3 ) oil and hulls placed in the rumen (RUM/RUM); and 4) oil infused in the abomasum and hulls placed in the rumen (ABO/ RUM). Data are the mean values with confidence intervals represented by vertical bars. *Mean values were different $(\mathrm{P}<0 \cdot 0001)$.

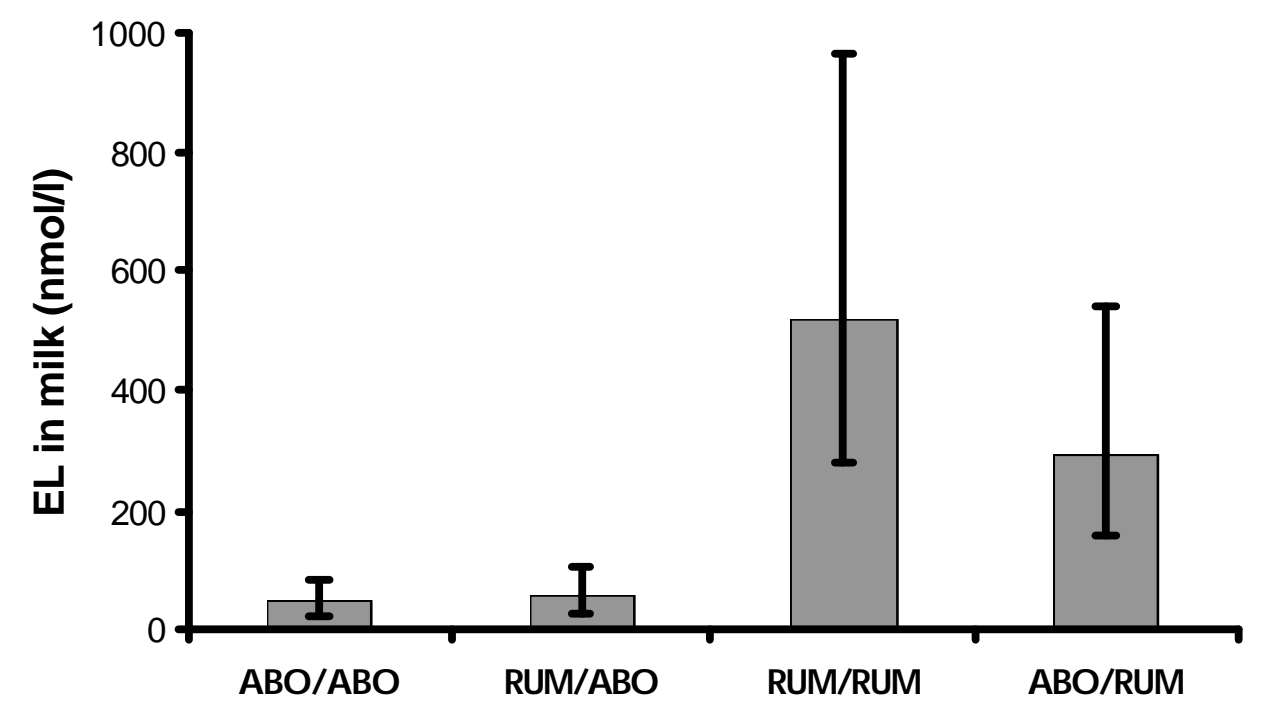

Figure 2D - Concentration of enterolactone (EL) in milk of dairy cows supplemented with flax hulls and flax oil. Treatments were: 1) oil and hulls infused in the abomasum (ABO/ABO); 2) oil placed in the rumen and hulls infused in the abomasum (RUM/ABO); 3 ) oil and hulls placed in the rumen (RUM/RUM); and 4) oil infused in the abomasum and hulls placed in the rumen (ABO/ RUM). Data are the mean values with confidence intervals represented by vertical bars. *Mean values were different $(\mathrm{P}<0 \cdot 0001)$. 
compared to those administered with flax products directly in the abomasum while plasma EL concentration was only 3 times higher.

Ruminal fluid and blood are dynamic media with body exchanges such as absorption while milk and urine may accumulate overtime (e.g. in the mammary gland). As a result, mammalian lignan EL is more likely concentrated in urine and milk than in ruminal fluid and blood. These results demonstrate that the main site for metabolism of flax lignans in dairy cows is the rumen. Therefore, ruminal microbiota may be the most important flora to target for plant lignan metabolism in order to increase concentration of mammalian lignan antioxidants (e.g. EL) in milk of dairy cows.

\section{Conclusions}

Any injuries to cells can alter various animal functions such as immunity and fertility and may have negative effects on productivity of dairy cows. Animals in transition period or challenged with stress (e.g. heat and shipping) may benefit of a feeding strategy including antioxidants to inhibit free radical attacks and enhance the antioxidant status. As supplementation with polyunsaturated FA increases susceptibility to oxidation, it is even more important to include antioxidants in the diet of animals fed these fat sources. The rumen is highly involved in metabolism of plant lignan antioxidants, suggesting that other antioxidants might be similarly affected by ruminal microbiota. Therefore, ruminal microbiota may be the most important flora to target for plant lignan metabolism in order to increase concentration of mammalian lignan antioxidants (e.g. EL) in milk of dairy cows. However, more research is required to improve our knowledge on metabolism of other antioxidants.

\section{Literature Cited}

ADLERCREUTZ, H.; MAZUR, W. Phyto-oestrogens and western diseases. Annals of Medicine, v.29, n.1, p.95-120, 1997.

AITKEN, S.L.; KARCHER, E.L.; REZEMAND, P. et al. Evaluation of antioxidant and proinflammatory gene expression in bovine mammary tissue during the periparturient period. Journal of Dairy Science, v.92, n.2, p.589-598, 2009.

ANDREWS, J.; VÁZQUEZ-AÑÓN, M.; BOWMAN, G. Fat stability and preservation of fatty acids with AGRADO antioxidant in feed ingredients used in ruminant rations. Journal of Dairy Science, v.89 (Suppl. 1), p.60 (Abstr.), 2006.

AURA, A.M.; OIKARINEN, S.; MUTANEN, M. et al. Suitability of a batch in vitro fermentation model using human faecal microbiota for prediction of conversion of flaxseed lignans to enterolactone with reference to an in vivo rat model.European Journal of Nutrition, v.45, n.1, p.45-51, 2006.

BANNWART, C.; ADLERCREUTZ, H.; WÄHÄLÄ, K. et al. Identification of the phyto-oestrogen 3 ',7 dihydroxyisoflavan, an isomer of equol, in human urine and cow's milk. Biomedical and Environmental Mass Spectrometry v.17, n.1, p.1-6, 1988.

BERNABUCCI, U.; RONCHI, B.; NARDONE, A. Influence of body condition score on relationships between metabolic status and oxidative stress in periparturient dairy cows. Journal of Dairy Science, v.88, n.6, p.2017-2026, 2005.

BORRIELLO, S.P.; SETCHELL, K.D.R.; AXELSON, M. et al. Production and metabolism of lignans by the human faecal flora. Journal of Applied Bacteriology v.58, n.1, p.37-43, 1985.

BOWEY, E.; ADLERCREUTZ, H.; ROWLAND, I. Metabolism of isoflavones and lignans by the gut microflora, a study in germfree and human flora associated rats. Food and Chemical Toxicology, v.41, n.5, p.631-636, 2003.

CABEL, M.C.; WALDROUP, P.W.; SHERMER, W.D. et al. Effects of ethoxyquin feed preservative and peroxide level on broiler performance. Poultry Science, v.67, n.12, p.1725-1730, 1988.

CASTILlO, C.; HERNANDEZ, J.; BRAVO, A. et al. Oxidative status during late pregnancy and early lactation in dairy cows. Veterinary Journal v.169, n.2, p.286-292, 2005.

CHARMLEY, E.; NICHOLSON, J.W.G. Influence of dietary fat source on oxidative stability and fatty acid composition of milk from cows receiving a low or high level of dietary vitamin E. Canadian Journal of Animal Science, v.74, n.4, p.657664, 1994.

CHARMLEY, E.; NICHOLSON, J.W.G; ZU, J.A. Effect of supplemental vitamin $E$ and selenium in the diet on vitamin $E$ and selenium levels and control of oxidized flavor in milk. Canadian Journal of Animal Science, v.73, n.2, p.453457, 1993.

CLARKE, S.D. Polynsaturated fatty acid regulation of gene transcription: a molecular mechanism to improve the metabolic syndrome. Journal of Nutrition v.131, n.4, p.1129-1132, 2001.

CÔRTES, C.; GAGNON, N.; BENCHAAR, C. et al. In vitro metabolism of flax lignans by ruminal and fecal microbiota of dairy cows. Journal of Applied Microbiology v.105, n.5, p.1585-1594, 2008.

DAY, A.J.; DUPONT, M.S.; RIDLEY, S. et al. Deglycosylation of flavonoid and isoflavonoid glycosides by human small intestine and liver [beta]-glucosidase activity. FEBS Letter, v.436, n.1, p.71-75, 1998.

DEHENNIN, L.; REIFFSTECK, A.; JONDET, M. et al. Identification and quantitative estimation of a lignan in human and bovine semen. Journal of Reproduction and Fertility v.66, n.1, p.305-309, 1982.

DHIMAN, T.R.; HELMINK, E.D.; MCMAHON, D.J. et al. conjugated linoleic acid content of milk and cheese from cows fed extruded oilseeds. Journal of Dairy Science, v.82, n.2, p.412-419, 1999.

DIBNER, J.J.; KITCHELL, M.L.; ATWELL, C.A. et al. The effect of dietary ingredients and age on themicroscopic structure of the gastrointestinal tract in poultry. Journal of Applied Poultry Research, v.5, n.1, p.70-77, 1996.

DICKINSON J.M.; SMITH, GR.; RANDER, R.D. et al. In vitro metabolism of formononetin and biochanin in bovine rumen fluid. Journal of Animal Science, v.66, n.8, p.1969-1973, 1988.

DRACKLEY, J. Biology of dairy cows during the transition period: the final frontier? Journal of Dairy Science, v.82, n.11, p.2259-2273, 1999.

ETHERINGT ON, W.G; KINSEL, M.L.; MARSH, W.W. Relationship of production to reproductive performance in Ontario dairy cows: herd level and individual animal descriptive statistics. Theriogenology, v.46, n.6, p.935-959, 1996.

FOCANT, M.; MIGNOLET, E.; MARIQUE, M.F. et al. The effect of vitamin E supplementation of cow diets containing rapeseed 
and linseed on the prevention of milk fat oxidation. Journal of Dairy Science, v. 81, n.4, p.1095-1101, 1998.

FRANKEL, E.N. Review: recent advances in lipid oxidation. Journal of the Science of Food and Agriculture. v.54, n.4, p.495-511, 1991 .

FRANKEL, E.N. Antioxidants. In: FRANKEL, E.N. (Ed.) Lipid oxidation. 2.ed. Bridgwater: The Oily Press, 2005. p.209258.

GAGNON, N.; CÔRTES, C.; DA SILVA, D. et al. Ruminal metabolism of flaxseed (Linum usitatissimum) lignans to the mammalian lignan enterolactone and its concentration in ruminal fluid, plasma, urine, and milk of dairy cows. British Journal of Nutrition (in press).

GRIMALDI, P.A. Fatty acid regulation of gene expression. Current Opinion in Clinical Nutrition and Metabolic Care, v.4, n.5, p.433-437, 2001

GRUNDY, S.M.; DENKE, M.A. Dietary influences on serum lipids and lipoproteins. Journal of Lipid Research, v.31, n.7, p. 1149-1161, 1990.

HANSEN-MØLLER, J.; KRISTENSEN, N.B. Determination of phytoestrogens in bovine plasma using liquid chromatography and tandem mass spectrometry. Journal of Animal Feed Science, v.13 (Suppl 1), p.315-318, 2004.

HAQUE, E.; CHAND, R.; KAPILA, S. Biofunctional properties of bioactive peptides of milk origin. Food Reviews International v. 25, n.1, p.28-43, 2009.

HAVEMOSE, M.S.; WEISBJERG, M.R.; BREDIE, W.L.P. et al. Oxidative stability ofmilk influenced by fatty acids, antioxidants, and copper derived from feed. Journal of Dairy Science, v.89, n.6, p.1970-1980, 2006.

HERDT, T.H. Fatty liver in dairy cows. Veterinary Clinics of North America: Food Animal Practice, v.4, n.2, p.269-287, 1988.

HERDT, T.H.; WENSING T.; HAAGSMAN, H.P. et al. Hepatic triacylglycerol synthesis during a period of fatty liver development in sheep. Journal of Animal Science, v.66, n. 8, p.1997-2013, 1988 .

HOIKKALA, A.A.; SCHIAVONI, E.; WAHALA, K. Analysis of phyto-oestrogens in biological matrices. British Journal of Nutrition, v.89 Suppl 1, p.S5-18, 2003.

JANSEN, GH.E.; ARTS, I.C.W.; NIELEN, M.W.F. et al. Uptake and metabolism of enterolactone and enterodiol by human colon epithelial cells. Archives of Biochemistry and Biophysics, v.435, n.1, p.74-82, 2005

KING, R.A.; MANO, M.M.; HEAD, R.J. Assessment of isoflavonoid concentrations in Australian bovine milk samples. Journal of Dairy Research, v.65, n.3, p.479-489, 1998.

KINSEL, M.L.; ETHERINGT ON, W.G. Factors affecting reproductive performance in Ontario dairy herds. Theriogenology, v.50, n.8, p.1221-1238, 1998.

KISO, Y. Antioxidative roles of sesamin, a functional lignan in sesame seed, ant its effect on lipid- and alcohol-metabolism in the liver: a DNA microarray study. Biofactors, v.21, n.1-4, 191-196, 2004.

LAMMING, GE.; DARWASH, A.O.; WATHES, D.C. et al. The fertility of dairy cattle in the UK: current status and future research. Journal of the Royal Agricultural Society of England v.159, p.82-93, 1998.

LESSARD, M.; GAGNON, N.; PETIT, H.V. Immune response of postpartum dairy cows fed flaxseed. Journal of Dairy Science v.86, n.8, p.2647-2657, 2003.

LIU, Z.; SAARINEN, N.M.; THOMPSON, L.U. Sesamin is one of the major precursors of mammalian lignans in sesame seed (Sesamum indicum) as observed in vitro and in rats. Journal of Nutrition v.136, n.4, p.906-912, 2006.

LUNDH, T.J.O.; PETTERSSON, H.I.; MARTINSSON, K. Comparative levels of free and conjugated plant estrogens in blood plasma of sheep and cattle fed estrogenic silage Journal of Agricultural and Food Chemistry, v.38, n.7, p.1012-1016, 1990.
MAIA, M.R.G; CHAUDHARY, L.C.; FIGUERES, L. et al. Metabolism of polyunsaturated fatty acids and their toxicity to the microflora of the rumen. Antonie Van Leeuwenhoek, v.91, n.4, p.303-314, 2007.

MEGAHED, G.A.; ANWAR, M.M.; WASFY, S.I. et al. Influence of heat stress on the cortisol and oxidant-antioxidants balance during oestrous phase in buffalo-cows (Bubalus bubalis): thermo-protective role of antioxidant treatment. Reproduction in Domestic Animals, v.43, n.6, p.672-677, 2008.

MILLER, J.K.; BRZEZINSKA-SLEBODZINSKA, E.; MADSEN, F.C. Oxidative stress, antioxidant and animals function. Journal of Dairy Science, v.76, n.9, p.2812-2823, 1993.

NICHOLSON, J.W.G; CHARMLEY, E. Oxidized flavour in milk: a Canadian perspective. International Dairy Federation Bulletin, v.257, p.11-17, 1991.

NICHOLSON, J.W.G; ST-LAURENT, A.M. Effect of forage type and supplemental dietary vitamin $\mathrm{E}$ on milk oxidative stability. Canadian Journal of Animal Science, v.71, n.4, p.11811186, 1991.

PETIT, H.V.; GAGNON, N.; GIGUÈRE, A. et al. Transfer of enterolactone in the milk of dairy cows fed flaxseed or flaxseed meal. In: NIZO DAIRY CONFERENCE, 4., 2005, Papendal, The Netherlands. Proceedings... Papendal: 2005. p.69.

PETIT, H.V.; GAGNON, N.; MIR, P. et al. Milk concentration of the mammalian lignan enterolactone, milk production, milk fatty acid profile, and digestibility of dairy cows fed diets containing whole flaxseed or flaxseed meal. Journal of Dairy Research (in press).

PLAIZIER, J.C.B.; KING, GJ.; DEKKERS, J.C.M. et al. Estimation of economic values of indices for reproductive performance in dairy herds using computer simulation. Journal of Dairy Science, v.80, n.11, p.2775-2783, 1997.

POOL-ZOBER, B.L.; ADLERCREUTZ, H.; GLEI, M. et al. Isoflavonoids and lignans have different potentials to modulate oxidative genetic damage in human colon cells. Carcinogenesis, v.21, n.6, p.1247-1252, 2000.

PRASAD, K. Antioxidant activity of secoisolariciresinol diglucoside-derived metabolites, secoisolariciresinol, enterodiol, and enterolactone. International Journal of Angiology, v.9, n.4, p.220-225, 2000

PURUP, S.; VESTERGAARD, M.; WEISBJERG M.R. et al. Possible role of enterolactone on mammary development and lactation in cattle. Journal of Animal Science, v.80 (Suppl. 1), p.910 (Abstr.), 2002.

RAFFAELLI, B.; HOIKKALA, A.; LEPPÄLÄ, E. et al. Enterolignans. Journal of Chromatography B, v.777, n.12, p.29-43, 2002 .

RAJESHA, J.; KOTAMBALLI, N.; MURTHY, K.N.C. et al. Antioxidant potentials of flaxseed by in vivo model. Journal of Agricultural and Food Chemistry, v.54, n.11, 3794-3799, 2006.

SAARINEN, N.M.; SMEDS, A.; MÄKELÄ, S.I. et al. Structural determinants of plant lignans for the formation of enterolactone in vivo. Journal of Chromatography B, v.777, n.1-2, p.311319, 2002.

SAARINEN, N.M.; POWER, KA; CHEN, J. et al. Lignans are accessible to human breast cancer xenografts in athymic mice. Nutrition and Cancer, v.60, n.2, p.245-250, 2008.

SETCHELL, K.D.; LAWSON, A.M.; MITCHELL, F.L. et al. Lignans in man and in animal species. Nature, v.287, n.5784, p.740-742, 1980

SIDHU, GS.; BROWN, M.A.; JOHNSON, A.R. Autoxidation in milk rich in linoleic acid. I. An objective method for measuring autoxidation and evaluating antioxidants. Journal of Dairy Research, v.42, n.1, p.185-195, 1975.

SIMOPOULOS, A.P. The importance of the ratio of omega-6/ omega-3 essential fatty acids. Biomedicine and Pharmacotherapy, v.56, n.8, p.365-379, 2002. 
STEINSHAMN, H.; PURUP, S.; THUEN, E. et al. Effects of clovergrass silages and concentrate supplementation on the content of phytoestrogens in dairy cow milk. Journal of Dairy Science, v.91, n.7, p.2715-2725, 2008.

STOPPER, H.; SCHMITT, E.; KOBRAS, K. Genotoxicity of phytoestrogens. Mutation Research v.574, n.1-2, p.139-155, 2005.

STRANG BD.; BERTICS, S.J.; GRUMMER, R.R. et al. Effect of long-chain fatty acids on triglyceride accumulation, gluconeogenesis, and ureagenesis in bovine hepatocytes. Journal of Dairy Science, v.81, n.3, p.728-739, 1998.

THOMPSON, L.U.; WARD, W.E. Flaxseed lignans: health benefits, bioavailability, and safety. In: GILANI, S.; ANDERSON, J. (Ed.) Phytoestrogens and health. Champaign: AOCS Press, 2002. p.405-426.
THOMPSON, L.U.; ROBB, P.; SERRAINO, M. et al. Mammalian lignan production from various foods. Nutrition and Cancer v.16, n.1, p.43-52, 1991.

VÁZQUEZ-AÑÓN, M.; NOCEK, J..; BOWMAN, G. et al. Effects of feeding a dietary antioxidant in diets with oxidized fat on lactation performance and antioxidant status of the cow. Journal of Dairy Science v.91, n.8, p.3165-3172, 2008.

TIMMONS, J.S.; WEISS, W.P.; PALMQUIST, D.L. et al. Relationships among dietary roasted soybeans, milk components, and spontaneous oxidized flavor of milk. Journal of Dairy Science v.84, n.2, p.2440-2449, 2001.

ZHOU, W.; WANG G; HAN, Z. et al. Metabolism of flaxseed lignans in the rumen and its impact on ruminal metabolism and flora. Animal Feed Science and Technology (in press), 2008. 